\title{
Laminosioptes cysticola in free-range chickens in Minas Gerais, Brazil
}

\author{
Laminosioptes cysticola em galinhas de fundo de quintal em Minas Gerais, Brasil
}

\author{
Nelson Rodrigo da Silva Martins ${ }^{I^{*}}$ José Sérgio de Resende $^{\mathrm{I}}$

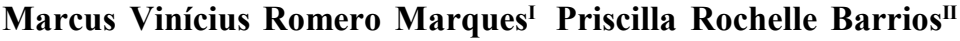 \\ André Almeida Fernandes ${ }^{\mathrm{I}}$ Lângia Colli Montresor ${ }^{\mathrm{III}}$ Lucas Maciel Cunha ${ }^{\mathrm{I}}$
}

- NOTE -

\section{ABSTRACT}

The subcutaneous acarid parasite Laminosioptes cysticola, the fowl cyst mite, has been found for a number of years in free-range chickens of peri-urban and rural Minas Gerais, forming collagen cysts which may be subsequently calcified after the parasite's death. The role of free-range chickens as hosts and the possible risk of food-borne human allergy, as a result of its consumption in feed, are considered.

Key words: Laminosioptes cysticola, fowl cyst mite, chicken, Gallus gallus domesticus.

\section{RESUMO}

O parasito acarino subcutâneo Laminosioptes cysticola tem sido encontrado em galinhas de subsistência periurbanas e rurais em Minas Gerais, formando cistos arredondados que podem calcificar sob a pele após a morte do parasito. Detalhes do parasitismo e do parasito são discutidos, sendo especulado o risco potencial humano em alergia de origem alimentar pelo consumo da carne da ave contendo os cistos.

Palavras-chave: Laminosioptes cysticola, ácaro do cisto subcutâneo, galinha, Gallus gallus domesticus.

The acarid Laminosioptes cysticola (Acariformes: Laminosioptidae, Vizioli, 1870), the fowl cyst mite, is a parasite principally of the subcutaneous (SC) tissues of chickens and other avian species. The occurrence of the parasite has been reported in chickens, turkeys, pheasants, geese, pigeons, psittacines and passerines worldwide (ARENDS, 2003; FAIN, 1981; LOOMIS, 1978; SMITH, 1997; SMOLSKASZYMCZEWSKA, 2000; TORO, 1999). Laminosioptes cysticola is most frequently found in the SC tissues (REIS, 1956), but has been reported in muscles, thoracoabdominal viscera, peritoneum and lungs (LOOMIS, 1978). An atypical infection was described with the clinical illness affecting the peripheral nerves of turkeys with incoordination, torticollis and drooping wings (SMITH, 1997). Mortality as associated to the parasitism has also been reported in poultry (SMOLSKA-SZYMCZEWSKA, 2000). L. cysticola was also detected in one $(1 / 100)$ free living pigeon in the city of Santiago of Chile (TORO, 1999) and in one female cowbird (Molothrus ater) with SC lumps on the neck and back (STEWART, 1963). Three new species, each representing a subgenus of genus Laminosioptes, were described in black-tailed hawfinch Coccothraustes migratorius (Passeriformes), Columbigallina minuta (Columbiformes) and in quaker parrot Myiopsitta

'Departamento de Medicina Veterinária Preventiva, Escola de Veterinária, Universidade Federal de Minas Gerais (UFMG), CP 567, Av. Antônio Carlos, 6627, 31270-010, Belo Horizonte, MG, Brasil. E-mail: nelson.rodrigo@pq.cnpq.br. *Autor para correspondência.

"Departamento de Veterinária, Universidade Federal de Lavras (UFLA), Lavras, MG, Brasil.

IIInstituto de Ciências Biológicas, Belo Horizonte, MG, Brasil. 
monachus (Psittaciformes), all found under the skin of birds which had died in the Antwerp Zoo after a short time in captivity (FAIN, 1981). The parasite penetrates into the subcutaneous tissue, where it feeds and eventually dies, the dead parasites are then encysted in collagen and cysts may evolve to calcification (REIS, 1956). The life cycle of the parasite is unknown and in free range chickens its occurrence may be overlooked, as subcutaneous tissues are not commonly inspected. The otherwise unseen parasite and cysts may be consumed with free range chicken meat, ingestion which may have a significance for eliciting food-borne allergy (OLSEN, 1998). Extensive cyst formations have been found in free-range chickens of rural Minas Gerais, Brazil. Considering the few previous reports found in the scientific literature in Brazil (REIS, 1939; REIS, 1956; URBAIN, 1916), this paper aims to provoke awareness and to describe some aspects of natural parasitism by L. cysticola in chickens.

Adult free-range chickens $(\mathrm{n}=6)$ of different origins of Minas Gerais state (metropolitan region of Belo Horizonte), representing 6 independent flocks, were submitted within years 2006-2008 for diagnosis of unspecified disease and necropsied. The subcutaneous tissue, muscular surface, respiratory system, thoraco-abdominal viscera and large peripheral nerves were examined macro and microscopically. Slides were prepared from subcutaneous (SC) collagen, tracheal mucosa, lungs, air sacs and intestinal mucosa for the bright-field microscopy (100 and 400x). Whitish cysts of approximately 1-2mm in diameter (Figure 1A and $1 \mathrm{~B}$ ) were found throughout the $\mathrm{SC}$ tissue of the cervical and thoraco-abdominal regions and thighs and legs. No evidence of SC inflammation, transudation, exudation or hemorrhages were seen. The microscopical observation of the SC collagen enabled the visualization of free (Figure 1C) and encysted (Figure 1D) Laminosioptes cysticola. One or more individuals could be encapsulated within the cyst, with cysts apparently made of overlapping protein coats (Figure 1D). In average the parasite measured $240 \mu \mathrm{m}$ in length and $70 \mu \mathrm{m}$ in width (midbody). The width was tapering from $80 \mu \mathrm{m}$ to $60 \mu \mathrm{m}$ toward the gnathosoma (Figure 1C). Efforts on morphological identification, field work and experimental bird infections are being carried out.

The occurrence of Laminosioptes cysticola in Brazil has been previously described (REIS, 1939; REIS, 1956), although no further scientific report was found. The presence of the parasite in present day subsistence chicken may be of importance, considering the growing interest for consumers for extensively raised poultry, such as organic, for which a few parasites may become of difficult control. The subcutaneous tissues, otherwise unchanged in gross aspect, with no inflammatory reaction, may not draw attention during processing for consumption, as cysts may be confused with fat deposits. It may be of importance for the public health professionals and officials the information concerning the possibility of an eventual risk, regarding the consumption of freerange chicken meat containing the parasite. Literature information on the epidemiology of the parasite describes its occurrence in different species, such as chicken, turkey, pheasant, goose and pigeon, and may indicate interspecies transmission, with pigeons playing a role for dissemination (STEWART, 1963; FAIN, 1981; SMITH, 1997; SMOLSKASZYMCZEWSKA, 2000). Considering that the parasite may be consumed with subsistence fowl meat, as the skin is rarely removed for cooking, it may be also of importance, for the sensitive people, the possibility of allergy elicited by the parasite tissues antigens, in this case by arthropod (OLSEN, 1998), as well as reported for helminth (NIEUWENHUIZEN et al., 2005). The eventual surge of hypersensitivity of unknown cause in allergic people might worth the investigation for history of free range chicken consumed. Hypersensitive humans may express a severe reaction to certain antigens, the most known being tropomyosin and chitin of crustacean arthropods. Tropomyosin is a crossreacting allergen present in insects, mites, crustaceans, mollusks, parasites and household arthropods (ARLIAN, 2002; KA HOU CHU et al., 2000; REESE et al., 1999). Chitin is a long-chain polymer of Nacetylglucosamine, a glucose derivative, being the main component of the cell walls of fungi, the exoskeletons of arthropods, such as crustaceans and insects (CAMPBELL, 1996).

Backyard chickens may function as an additional host for the parasite interspecies circulation and source for avian fauna in our region. Laminosioptes cysticola has been previously described in passerines (FAIN, 1981; STEWART, 1963), a psittacine (FAIN, 1981) and pigeons (FAIN, 1981; TORO, 1999), both playing roles in harbouring and dissemination. As an important protein source in human nutrition for rural and peri-urban, especially poor, communities, and the growing market for extensively raised poultry, the non-industrial chickens are raised free-range allowing the re-emergence of presently rare conditions for indoor poultry. The occurrence of Laminosioptes cysticola in free-range chickens kept for subsistence in Minas Gerais may worth the attention regarding human food-borne allergy.

Ciência Rural, v.40, n.6, jun, 2010. 


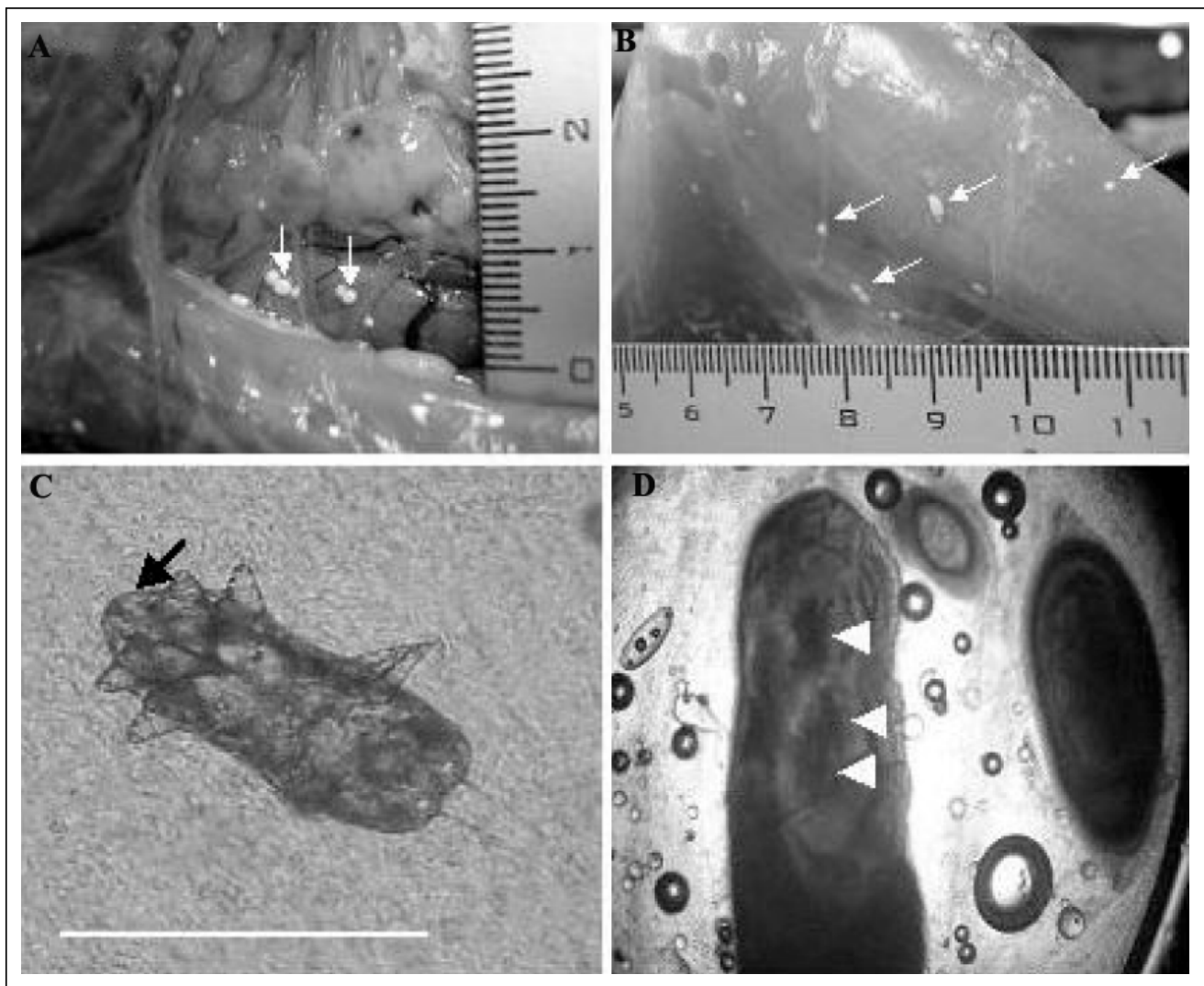

Figure 1 - A) Subcutaneous cysts (arrows) of Laminosioptes cysticola in the cervical region of an adult chicken, with the thymus, jugular vein and vagus visible. B) Cysts of Laminosioptes cysticola visible onto the thigh and leg (arrows). Cysts are of approximately 0.5 to $1.5 \mathrm{~mm}$ in diameter (ruler smallest subdivision=1mm). C) The free subcutaneous parasite was found in the subcutaneous collagen. Note the acarid long tapering shape. In the anterior part, the exposed gnathosome (arrow) and the extended front legs are visible. The approximate dimensions of Laminosioptes cysticola are $240 \mathrm{~m}$ in length and $70 \mathrm{~m}$ in width. 400X. Bar: $240 \mathrm{~m}$. D) Within cysts, darker structures of dead parasites (white arrow heads) are visible. 40X.

\section{ACKNOWLEDGEMENTS}

The authors are indebted to CAPES, CNPq, FAPEMIG and FEP/MVZ for support. This study takes part of the INCT-IGSP (Instituto Nacional de Ciência e Tecnologia Informação Genético-Sanitária da Pecuária Brasileira).

\section{REFERENCES}

ARENDS, J.J. External parasites and poultry pests. In: SAIF, Y.M. et al. Diseases of poultry. 11.ed. Ames: Iowa State, Blackwell Publishing, 2003. 1231p. ISBN 0-8138-0423-X.

ARLIAN, L.G. Arthropod allergens and human health. Annual Review of Entomology, v.47, p.395-433, 2002. Available from: http://arjournals.annualreviews.org/doi/pdf/10.1146/ annurev.ento.47.091201.145224. Accessed: April 23, 2010. doi:10.1146/annurev.ento.47.091201.145224.

CAMPBELL, N.A.; J.B. REECE. Biology. 4.ed. New York: Benjamin Cummings, 1996. 1159p. ASIN: B000VT3CEG.
FAIN, A. Notes on the genus Laminosioptes Megnin, 1880 (Acari, Astigmata) with description of three new species. Systematic Parasitology, v.2, n.2, p.123-169, 1981. Available from: $<$ http://www.springerlink.com/content/r1h58433162502p0>. Accessed: May 25, 2010. doi: 10.1007/BF00009900.

KA HOU CHU et al. Tropomyosin is the major mollusk allergen: reverse transcriptase polymerase chain reaction, expression and IgE reactivity Marine Biotechnology, v.2, n.5, p. 499509, 2000. Available from: <http://www.springerlink.com/ content/u6fgtcn136065n89/fulltext.pdf $>$. Accessed: Apr. 22, 2010. doi: $10.1007 / \mathrm{s} 101260000035$.

LOOMIS, E.C. External parasites. In: HOFSTAD, M.S. et al. Diseases of poultry. 7.ed. Ames: Iowa State Univerity, 11978. p.667-704. ISBN 0-8138-0430-2.

REESE, G. et al. TROPOMYOSIN: an invertebrate panallergen. International Archives of Allergy and Immunology, v.119, p.247-258, 1999. Available from: <http:/ / c o n t e n t. k a r g e r. c o m/ produkted b/ produkte.asp? aktion $=$ showabstract\&artikeln 
$\mathrm{r}=24201$ \&ausgabe $=226021$ \&produktnr $=224161>$. Accessed: Apr. 22, 2010. doi: 10.1159/000024201.

NIEUWENHUIZEN, N. et al. Food allergy, dermatologic diseases, and anaphylaxis. Exposure to the fish parasite Anisakis causes allergic airway hyperreactivity and dermatitis. Journal of Allergy and Clinical Immunology, v.117, n.5, p.1098 1105, 2005. Available from: <http://www.sciencedirect.com/ science?_ob=ArticleURL\&_udi=B6WH4-4JVXWV6V\& user $=686413 \&$ coverDate $=05 \% 2 \mathrm{~F} 31 \% 2 \mathrm{~F} 2006 \&$ rdoc $=1 \&$ fint $=$ high $\&$ orig =search\&_sort $=$ d\&_docanchor $=\&$ view $=c$ \&_searchStrId $=1306652288 \&$ \&erunOrigin $=$ google \&_acct $=$ C $000037539 \&$ \&ersion $=1 \&$ \&urlVersion $=$ 0\&_userid $=686413 \& \mathrm{md} 5=209 \mathrm{e} 997 \mathrm{ba} 352782 \mathrm{cc} 3997 \mathrm{~cd} 4 \mathrm{be} 809 \mathrm{~d} 4 \mathrm{~d}>$. Accessed: Apr. 22, 2010. doi:10.1016/j.jaci.2005.12.1357.

OLSEN, A.R. Regulatory action criteria for filth and other extraneous materials. II. Allergenic mites: an emerging food safety issue. Regulatory Toxicology and Pharmacology, v.28, p.190198, 1998. Available from: <http://seafood.ucdavis.edu/sanitation/ regulatory $\% 20$ action $\% 20$ criteria $\% 20$ for $\% 20$ filth .pdf $>$. Accessed: Apr. 23, 2010. doi:10.1006/rtph.1998.1270.

REIS, J. Alguns parasitas de Gallus gallus (L.) verificados em São Paulo. Arquivos do Instituto Biológico, v.10, p.147153,1939
REIS, J.; NÓBREGA, P. Doenças produzidas por protozoários e artrópodes parasitas. In: ; . Tratado de doenças das aves. 2.ed. São Paulo: Melhoramentos, 1956. p.277279 .

SMITH, K.E. et al. Clinical illness in a wild turkey with Laminosioptes cysticola infestation of the viscera and peripheral nerves. Avian Pathology, v.41, n.2, p.484-489, 1997. Available from: http://www.jstor.org/stable/1592211. Accessed: May 25, 2010

SMOLSKA-SZYMCZEWSKA, B. Laminosioptes cysticola, acariasis in poultry. Medycyna Weterynaryja, v.56, n.6, p.349-412, 2000.

STEWART, P.A. Abnormalities among brown-headed cowbirds trapped in Alabama. Bird Banding, v.XXXIV, p.199-202, 1963. Available from: http://www.jstor.org/stable/4511029. Accessed: May 25, 2010.

TORO, H. et al. Health status of free-living pigeons in the city of Santiago. Avian Pathology, v.28, n.6, p.619-623, 1999. Available from: http://dx.doi.org/10.1080/03079459994416. Accessed: May 25, 2010

URBAIN, G. Meningo-encephalomyelite das galinhas. Spirillose? Revista de Veterinária e Zootechnia, p.349$351,1916$. 